\begin{tabular}{ccc} 
JURNAL BIOTERDIDIK: WAHANA EKSPRESI ILMIAH & \begin{tabular}{c} 
e-ISSN: \\
$2621-5594$ \\
p-ISSN: \\
\hline Jurnal Bioterdidik
\end{tabular} Vol. 9 No. 3, Desember 2021, page. 226-233 \\
http://jurnal.fkip.unila.ac.id/index.php/JBT/ & doi: $10.2302-1276$ \\
\hline
\end{tabular}

\title{
Analisis Preliminery Research Phase dengan Model Plomp Sebagai Dasar Pengembangan Modul Belajar Bermuatan Hasil Riset Untuk Mahasiswa
}

\author{
Nurul Fauziah*', Iffa Ichwani Putri, Oktariani \\ Program Studi Pendidikan Biologi, Fakultas Keguruan dan Ilmu Pendidikan, Universitas Islam Riau \\ *e-mail: fauziahnurul@edu.uir.ac.id
}

Received: November 11,2021 Accepted: December 24, 2021 Online Published: December 30, 2021

\begin{abstract}
Preliminery Research Phase Analysis using Plomp Model as a Basis Development of Learning Modules Biology with Research Results for Student. The purpose of this study is to describe the preliminery research phase data obtained as a basis for the development of learning and learning modules containing research results that will be developed later. The development model used in this study is the Plomp model which has been carried out until the initial investigation data stage. Instruments of data collections using interviews, observations, and questionnaires. The results revealed in the analysis of the Semester Learning Plan (RPS) there were thirteen topics in learning and learning. Student problem questionnaire revealed that students do not yet have a learning and learning module with a percentage of $13.71 \%$. Student needs questionnaire revealed that students strongly agree the need to develop learning and learning modules containing research results with a percentage of 100\%. The learning and learning module that has been used in the learning process does not meet the standards of the Ministry of Research, Technology, and Higher Education Directorate General of Learning and Student Affairs Directorate of Learning in 2017.
\end{abstract}

Keywords: learning module, learning devices, research results

\begin{abstract}
Abstrak: Analisis Preliminery Research Phase dengan Model Plomp Sebagai Dasar Pengembangan Modul Belajar Bermuatan Hasil Riset Untuk Mahasiswa. Tujuan penelitian ini adalah untuk mendeskripsikan data preliminery research phase yang didapatkan sebagai dasar pengembangan modul belajar dan pembelajaran bermuatan hasil riset yang akan dikembangkan nantinya. Model pengembangan yang digunakan dalam penelitian ini adalah model Plomp yang telah dilakukan sampai tahap data investigasi awal. Instrumen pengumpulan data menggunakan wawancara, observasi dan angket. Hasil penelitian mengungkapkan pada analisis Rencana Pembelajaran Semester (RPS) terdapat 13 topik dalam perkuliahan belajar dan pembelajaran. Angket permasalahan mahasiswa mengungkapkan mahasiswa belum memiliki modul bioteknologi dengan presentase $13,71 \%$. Angket kebutuhan mahasiswa mengungkapkan mahasiswa sangat setuju perlu dikembangkannya modul belajar dan pembelajaran bermuatan hasil riset dengan presentase 100\%. Modul belajar dan pembelajaran yang telah digunakan dalam proses pembelajaran belum memenuhi standar dari Kementrian Riset, Teknologi, dan Pendidikan Tinggi Direktorat Jenderal Pembelajaran dan Kemahasiswaan Direktorat Pembelajaran tahun 2017.
\end{abstract}

Kata kunci: hasil riset, modul pembelajaran, studi pendahuluan 


\section{PENDAHULUAN}

Belajar dan pembelajaran pendidikan biologi adalah salah satu mata kuliah wajib di semester tiga yang dipelajari di Program Studi Pendidikan Biologi FKIP UIR. Matakuliah ini mempelajari tentang berbagai macam strategi yang bisa digunakan dalam proses belajar dan mengajar mengenai ilmu biologi. Mata kuliah belajar dan pembelajaran pendidikan biologi membutuhkan bahan ajar dengan proses ilmiah yang lebih spesifik berupa modul yang dilengkapi dengan hasil riset tentang strategi yang digunakan dalam proses belajar dan mengajar biologi.

Sebelum dilakukannya proses pengembangan modul, terlebih dahulu harus dilakukan preliminery research phase (tahapan pendahuluan penelitian) sebagai dasar pengembangan modul tersebut, dari analisis pendahuluan akan terungkap apakah diperlukan adanya pengembangan modul dan jika telah dilakukannya pengembangan modul apakah akan memberikan sumbangan yang positif terhadap hasil belajar dan proses perkuliahan di kelas. Preliminary research phase terdiri dari beberapa kegiatan, diantaranya: analisis RPS mata kuliah, wawancara, analisis bahan ajar yang digunakan, angket permasalahan mahasiswa, dan angket kebutuhan mahasiswa terhadap mata kuliah belajar dan pembelajaran pendidikan biologi. Hal ini sejalan dengan hasil penelitian (Fauziah, Nurul., Putri, 2019) tentang analisis perangkat pembelajaran sebagai dasar pengembangan modul bioteknologi bermuatan hasil riset yang menyatakan bahwa berdasarkan hasil analisis preliminary research phase yang dilakukan maka diperlukan adanya pengembangan modul bioteknologi bermuatan hasil riset.

Berdasarkan hasil pengamatan yang dilakukan oleh peneliti sendiri sebagai dosen pengampu mata kuliah, telah ditemukan beberapa permasalahan dalam proses perkuliahan di kelas dan berkaitan dengan hasil belajar, diantaranya: pertama, mahasiswa belum menggunakan modul dalam perkuliahan dan dosen mendominasi jalannya perkuliahan. Kedua, rujukan yang digunakan oleh mahasiswa dalam membuat makalah dan tugas presentasinya masih banyak merujuk pada blog-blog yang belum tervalidasi dengan jelas kebenaran tulisannya, sehingga mengakibatkan timbulnya pemahaman yang ambigu pada materi yang dipresentasikan.

Ketiga, dosen belum menggunakan modul yang bermuatan hasil riset dalam perkuliahan belajar dan pembelajaran pendidikan biologi. Bahan ajar yang dijadikan literatur oleh dosen banyak berupa buku dan hasil riset tentang pembelajaran biologi yang hanya dipaparkan di kelas sebagai contoh dalan menjelaskan materi, sehingga mahasiswa menjadi kurang memhami contoh yang yang diberikan. Hal ini, dapat diatasi dengan menggunakan modul belajar pembelajaran pendidikan biologi bermuatan hasil riset yang memuat hasil riset terbaru, baik dari jurnal nasional ataupun internasional tentang strategi belajar mengajar yang digunakan dan proses pembelajaran biologi.

Belajar tentang teori dan memahami contoh berdasarkan hasil riset yang berkaitan dengan teori/materi tersebut, diharapkan akan dapat meningkatkan pemahaman mahasiswa terhadap mata kuliah belajar dan pembelajaran biologi, sehingga selain meningkatkan hasil belajar juga akan memudahkan mahasiswa nantinya dalam menentukan strategi belajar dan mengajar apa yang akan tepat digunakan dalam memecahkan permasalahan tugas akhir/skripsinya.

Hal ini sejalan dengan hasil penelitian yang dilakukan oleh (Parmin., Peniati, 2012) tentang pengembangan modul mata kuliah strategi belajar mengajar IPA berbasis hasil penelitian pembelajaran yang menyatakan bahwa hasil-hasil penelitian yang telah terpublikasikan di jurnal layak digunakan sebagai rujukan pengembangan modul karena lebih aplikatif dan memenuhi unsur kekinian dan efektif digunakan dalam pembelajaran. 
Keempat, bahan ajar yang digunakan mahasiswa tidak memiliki warna dan gambar yang aplikatif sehingga membuat mahasiswa kurang termotivasi untuk membaca. (Ellizar, 2009) menyatakan dengan adanya gambar berwarna, mahasiswa termotivasi belajar karena mahasiswa lebih berminat membaca modulnya. Berdasarkan hal tersebut, akan dilakukan analisis preliminary research phase menggunakan model pengembangan PLOMP sebagai dasar pengembangan modul belajar dan pembelajaran pendidikan biologi bermuatan hasil riset untuk mahasiswa.

\section{METODE}

Jenis penelitian ini adalah penelitian pemgembangan, dengan cara mendeskripsikan hasil yang didapatkan. Dasar pengembangan modul belajar dan pembelajaran bermuatan hasil riset untuk mahasiswa Pendidikan Biologi menggunakan model (Plomp, Tjeerd., Nieeven, 2013) yang terdiri dari tiga tahap, yaitu tahap investigasi awal (preliminary investigation), tahap prototipe (prototype phase), dan tahap penilaian (assesment phase). Pada penelitian ini hanya dilakukan sampai tahap investigasi awal saja.

Tahap preliminary investigation bertujuan menetapkan dan mendefinisikan syarat-syarat yang dibutuhkan dalam pengembangan modul. Ada lima langkah pokok dalam tahap preliminary, yaitu: analisis RPS, wawancara terhadap dosen mata kuliah belajar dan pembelajaran, analisis bahan ajar yang digunakan, dan analisis permasalahan dan kebutuhan mahasiswa Program Studi Pendidikan Biologi di Universitas Islam Riau.

Subjek pada penelitian ini adalah mahasiswa Program Studi Pendidikan Biologi Universitas Islam Riau FKIP UIR angkatan 2020 sebanyak 46 orang untuk mengisi angket permasalahan dan angket kebutuhan modul bioteknologi yang akan dikembangkan. Jenis data pada penelitian ini terdiri dari data kualitatif yang didapatkan dari wawancara, observasi dan angket.

Tekik analisis data dalam penelitian ini adalah analisis data deskriptif. Menurut (Sastroadmojo, 2018) untuk menganalisis angket yang telah diperoleh maka peneliti mengubah data tersebut dalam bentuk persentase dengan menggunakan rumus persentase, yaitu:

$$
\mathrm{P}=\frac{\mathrm{F}}{\mathrm{N}} \times 100 \%
$$

Keterangan:

$\mathrm{P}=$ Persentase

$\mathrm{F}=$ Frekuensi Skor Jawaban

$\mathrm{N}=$ Jumlah Responden

\section{HASIL DAN PEMBAHASAN}

Data Investigasi Awal (Preliminery Investigation). Berdasarkan analisis RPS yang digunakan dalam perkuliahan belajar dan pembelajaran, maka didapatkan tiga belas topik utama dalam pembelajaran belajar dan pembelajaran. Topik pada perkuliaham belajar dan pembelajaran dapat dilihat pada Tabel 1. 
Tabel 1. Topik Perkuliahan yang Terdapat pada Mata Kuliah Belajar dan Pembelajaran

\begin{tabular}{cl}
\hline No. & \multicolumn{1}{c}{ Bahan Kajian } \\
\hline 1. & Teori Belajar dan Pembelajaran \\
\hline 2. & Tujuan dan Prinsip Pembelajaran Biologi \\
\hline 3. & $\begin{array}{l}\text { Materi dan Pengalaman Belajar Biologi serta Keterampilan } \\
\text { Dasar Guru }\end{array}$ \\
\hline 4. & Motivasi dalam Belajar \\
\hline 5. & Masalah-masalah Belajar \\
\hline 6. & Sumber Belajar dan Media Pembelajaran \\
\hline 7. & Peta Konsep \\
\hline 8. & Pendekatan dalam Pembelajaran Biologi \\
\hline 9. & Metode dalam Pembelajaran Biologi \\
\hline 10. & Model dalam Pembelajaran Biologi \\
\hline 11. & Model Pembelajaran Kooperatif \\
\hline 12. & Aspek-aspek Psikologis dalam Pembelajaran \\
\hline 13. & Evaluasi Belajar dan Pembelajaran \\
\hline
\end{tabular}

Wawancara kepada Dosen Pengampu Mata Kuliah Belajar dan Pembelajaran. Berdasarkan hasil wawancara yang dilakukan oleh peneliti kepada dosen pengampu mata kuliah belajar dan pembelajaran, telah ditemukan beberapa permasalahan dalam proses perkuliahan di kelas dan berkaitan dengan hasil belajar, diantaranya: pertama, mahasiswa belum menggunakan modul dalam perkuliahan dan dosen mendominasi jalannya perkuliahan. Kedua, rujukan yang digunakan oleh mahasiswa dalam membuat makalah dan tugas presentasinya masih banyak merujuk pada blog-blog yang belum tervalidasi dengan jelas kebenaran tulisannya, sehingga mengakibatkan timbulnya pemahaman yang ambigu pada materi yang dipresentasikan.

Ketiga, dosen belum menggunakan modul yang bermuatan hasil riset dalam perkuliahan belajar dan pembelajaran pendidikan biologi. Bahan ajar yang dijadikan literatur oleh dosen banyak berupa buku dan hasil riset tentang pembelajaran biologi yang hanya dipaparkan di kelas sebagai contoh dalan menjelaskan materi, sehingga mahasiswa menjadi kurang memhami contoh yang yang diberikan. Keempat, bahan ajar yang digunakan mahasiswa tidak memiliki warna dan gambar yang aplikatif sehingga membuat mahasiswa kurang termotivasi untuk membaca.

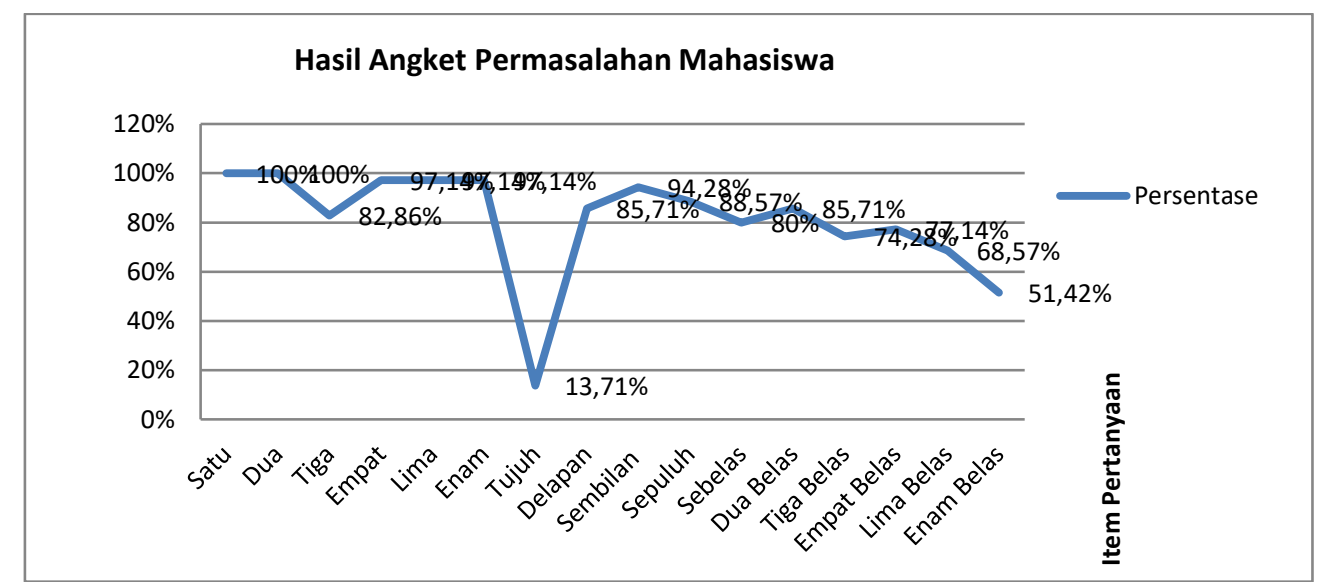

Gambar 1. Hasil Angket Permasalahan Mahasiswa 
Analisis Angket Permasalahan Mahasiswa dalam Perkuliahan Belajar dan Pembelajaran. Hasil analisis permasalahan mahasiswa dalam perkuliahan belajar dan pembelajaran yang telah diisi oleh 35 orang mahasiswa Program Studi Pendidikan Biologi FKIP Universitas Islam Riau angkatan 2020 yang telah menyelesaikan mata kuliah belajar dan pembelajaran dapat dilihat pada Gambar 1.

Analisis Angket Kebutuhan Mahasiswa dalam Perkuliahan Belajar dan Pembelajaran. Hasil analisis kebutuhan mahasiswa dalam perkuliahan belajar dan pembelajaran yang telah diisi oleh 35 orang mahasiswa Program Studi Pendidikan Biologi FKIP Universitas Islam Riau angkatan 2020 yang telah menyelesaikan mata kuliah belajar dan pembelajaran dapat dilihat pada Gambar 2.

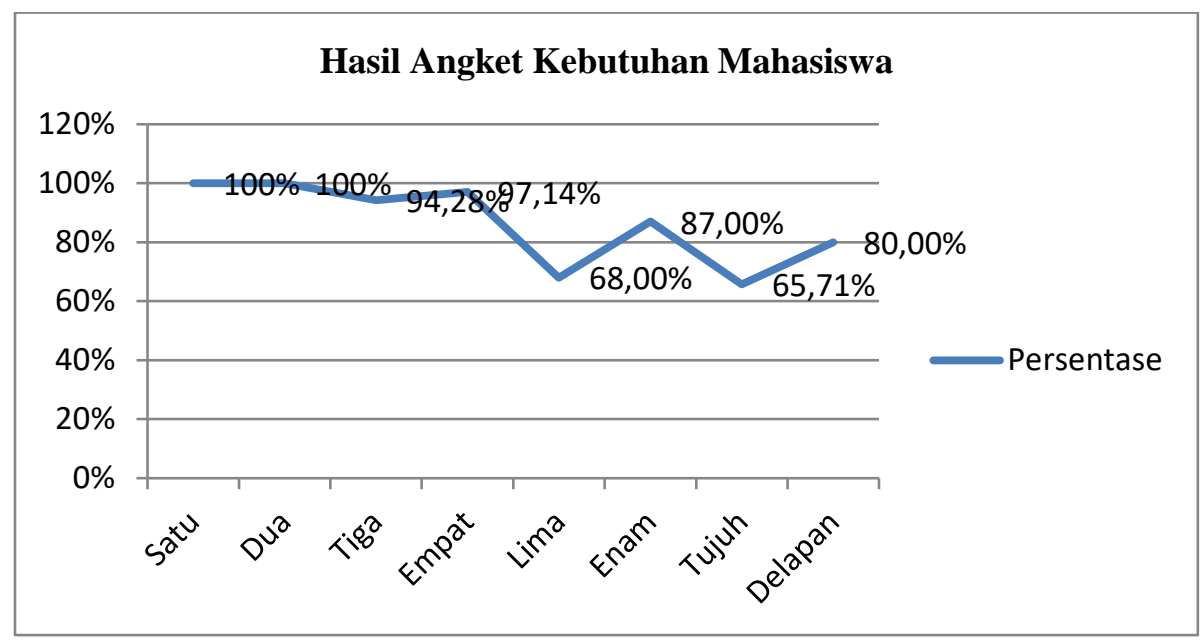

Gambar 2. Hasil Angket Kebutuhan Mahasiswa

Analisis Preliminery Research Phase. Modul belajar dan pembelajaran bermuatan hasil riset dikembangkan menggunakan model Plomp yang terdiri dari tiga tahapan, yaitu preliminery research phase, prototyping phase, dan assessment phase. Pada penelitian ini hanya dilakukan pada tahapan awal saja yaitu preliminery research phase yang bertujuan untuk mengumpulkan data awal sebagai dasar pengembangan modul belajar pembelajaran bermuatan hasil riset. Hal ini sejalan dengan hasil penelitian (Fauziah, Nurul., Putri, 2019) tentang analisis perangkat pembelajaran sebagai dasar pengembangan modul bioteknologi bermuatan hasil riset yang menyatakan bahwa berdasarkan hasil analisis preliminary research phase yang dilakukan maka diperlukan adanya pengembangan modul bioteknologi bermuatan hasil riset. Hal ini juga sependapat dengan hasil penelitian (Marhalena, 2016) yang menyatakan bahwa analisis perangkat pembelajaran perlu dilakukan karena akan menjadi dasar dalam pengembangan modul yang dikembangkan.

Preliminery research phase yang pertama dilakukan adalah menganalisis RPS (Rencana Pembelajaran Semester) yang digunakan di dalam perkuliahan belajar dan pembelajaran. Berdasarkan analisis terhadap RPS yang digunakan, terdapat tiga belas bahan kajian atau topik yang dikaji di dalam perkuliahan belajar dan pembelajaran. Kesesuaian RPS yang digunakan dengan bahan kajian yang dipelajari akan memudahkan tercapainya tujuan perkuliahan yang harus dicapai oleh mahasiswa pada mata kuliah belajar dan pembelajaran. Hal ini sejalan dengan pendapat (Kusuman, Airlangga., Mukhidin., 2016) yang menyatakan bahwa pendidik memegang peran sentral terhadap proses dan hasil pendidikan karena pendidik merupakan subjek yang diharapkan mampu 
menganalisis kurikulum menjadi lebih operasional dan spesifik dalam bentuk silabus/RPS maupun bahan ajar yang akan digunakan.

Preliminery research phase yang kedua dilakukan adalah melakukan wawancara terhadap dosen pengampu mata kuliah belajar dan pembelajaran. Dari hasil wawancara terungkap bahwa mahasiswa belum menggunakan modul dalam perkuliahan dan dosen mendominasi jalannya perkuliahan. Rujukan yang digunakan oleh mahasiswa dalam membuat makalah dan tugas presentasinya masih banyak merujuk pada blog-blog yang belum tervalidasi dengan jelas kebenaran tulisannya, sehingga mengakibatkan timbulnya pemahaman yang ambigu pada materi yang dipresentasikan.

Dosen belum menggunakan modul yang bermuatan hasil riset dalam perkuliahan belajar dan pembelajaran. Bahan ajar yang dijadikan literatur oleh dosen banyak berupa buku dan hasil riset tentang pembelajaran biologi yang hanya dipaparkan di kelas sebagai contoh dalan menjelaskan materi, sehingga mahasiswa menjadi kurang memhami contoh yang yang diberikan. Hal ini, dapat diatasi dengan menggunakan modul belajar pembelajaran pendidikan biologi bermuatan hasil riset yang memuat hasil riset terbaru, baik dari jurnal nasional ataupun internasional tentang strategi belajar mengajar yang digunakan dan proses pembelajaran biologi.

Belajar tentang teori dan memahami contoh berdasarkan hasil riset yang berkaitan dengan teori/materi tersebut, diharapkan akan dapat meningkatkan pemahaman mahasiswa terhadap mata kuliah belajar dan pembelajaran, sehingga selain meningkatkan hasil belajar juga akan memudahkan mahasiswa nantinya dalam menentukan strategi belajar dan mengajar apa yang akan tepat digunakan dalam memecahkan permasalahan tugas akhir/skripsinya. Hal ini sejalan dengan hasil penelitian yang dilakukan (Parmin., Peniati, 2012) tentang pengembangan modul mata kuliah strategi belajar mengajar IPA berbasis hasil penelitian pembelajaran yang menyatakan bahwa hasil-hasil penelitian yang telah terpublikasikan di jurnal layak digunakan sebagai rujukan pengembangan modul karena lebih aplikatif dan memenuhi unsur kekinian dan efektif digunakan dalam pembelajaran.

Bahan ajar yang digunakan mahasiswa tidak memiliki warna dan gambar yang aplikatif sehingga membuat mahasiswa kurang termotivasi untuk membaca. (Ellizar, 2009) menyatakan dengan adanya gambar berwarna, mahasiswa termotivasi belajar karena mahasiswa lebih berminat membaca modulnya.

Preliminery research phase selanjutnya yang dilakukan adalah melakukan analisis terhadap angket permasalahan dan angket kebutuhan mahasiswa dalam perkuliahan belajar dan pembelajaran. Berdasarkan hasil angket permasalahan dapat diungkapkan bahwa mahasiswa belum memiliki modul belajar dan pembelajaran untuk menunjang proses perkuliahan dengan persentase $13.71 \%$. Sedangkan hasil angket analisis kebutuhan mahasiswa mengungkapkan perlu adanya pengembangan modul belajar dan pembelajaran bermuatan hasil riset dengan persentase $100 \%$.

Mahasiswa juga diminta menentukan warna dan jenis tulisan yang dominan yang akan dipakai di dalam modul belajar dan pembelajaran tersebut. Warna yang dipilih oleh mahasiswa untuk sampul modul didominasi oleh warna hijau dan untuk isi modul didominasi oleh warna putih, sedangkan untuk jenis tulisan pada sampul dan isi modul didominasi oleh jenis tulisan times new roman. Analisis angket permasalahan dan angket kebutuhan mahasiswa perlu dilakukan supaya modul yang akan dikembangkan nanti sesuai dengan kebutuhan mahasiswa dan dapat menunjang perkuliahan belajar dan pembelajaran. Hal ini sejalan dengan pendapat (Aflah, Mita Nur., Rahmani, 2018) yang menyatakan bahwa analisis kebutuhan memiliki peranan penting di dalam pengajaran 
karena melalui analisis kebutuhan pendidik, peserta didik, bahan ajar, prosedur pengajaran, semua dapat terhubung dengan harmonis guna meningkatkan kualitas pembelajaran.

Hasil analisis pada bahan ajar yang digunakan pada perkuliahan belajar dan pembelajaran mengungkapkan bahwa bahan ajar yang digunakan sudah memiliki cakupan materi yang baik, kebahasaan yang baik dan mudah dipahami, dan penyajian yang baik, tetapi banyak materi yang dituntut di RPS tidak terdapat pada satu bahan ajar saja, tapi harus menggunakan banyak sumber bahan ajar. Selain itu komponen kegrafikan bahan ajar yang digunakan belum sesuai dengan acuan standar bahan ajar untuk mahasiswa, seperti tidak adanya halaman prakata, daftar tabel, daftar lampiran, lembar evaluasi, dan belum memiliki daftar pustaka pada setiap bab nya. Panduan penyusunan bahan ajar untuk tingkat universitas telah ditetapkan sesuai dengan panduan penyusunan perangkat pembelajaran dan bahan ajar yang telah ditetapkan oleh (Pembelajaran, 2017)

\section{SIMPULAN}

Berdasarkan data preliminery investigation yang telah didapatkan, maka dapat dilakukan pengembangan modul belajar dan pembelajaran bermuatan hasil riset untuk mahasiswa.

\section{UCAPAN TERIMA KASIH}

Peneliti mengucapkan terima kasih kepada Departemen Penelitian dan Pengabdian kepada Masyarakat sesuai dengan kontrak penelitian tahun anggaran 2020, Nomor: 207/KONTRAK/LPPM-UIR/5-2020.

\section{DAFTAR RUJUKAN}

Aflah, Mita Nur., Rahmani, E. F. (2018). Analisa Kebutuhan (Need Analysis) Mata Kuliah Bahasa Inggris untuk Mahasiswa Kejuruan. Jurnal Pendidikan Bahasa, 7(1), 77-89. Retrieved from https://journal.ikippgriptk.ac.id/index.php/bahasa/article/view/828

Ellizar. (2009). Models of Teaching by Constructivism Approach with Module. Jurnal Kependidikan Triadik, 12(1), 7-16. Retrieved from http://repository.unib.ac.id/312/1/Judul 2 Ellizar.pdf

Fauziah, Nurul., Putri, I. I. (2019). Analisis Perangkat Pembelajaran Sebagai Dasar Pengembangan Modul Bioteknologi Bermuatan Hasil Riset Untuk Mahasiswa Biologi. Jurnal Bioterdidik, 7(6), 7-13. Retrieved from http://jurnal.fkip.unila.ac.id/index.php/JBT/search

Kusuman, Airlangga., Mukhidin., H. B. (2016). Pengembangan Bahan Ajar Mata Pelajaran Dasar dan Pengukuran Listrik untuk Sekolah Menengah Kejuruan. Jurnal Pendidikan Teknologi Dan Kejuruan, 23(1), 28-39. Retrieved from https://journal.uny.ac.id/index.php/jptk/article/view/9352

Marhalena. (2016). Pengembangan Modul Ekologi Hewan Bermuatan Hasil Riset. Universitas Negeri Padang, Padang.

Parmin., Peniati, E. (2012). Pengembangan Modul Mata Kuliah Strategi Belajar Mengajar IPA Berbasis Hasil Penelitian Pembelajaran. Jurnal Pendidikan IPA Indonesia, 1(1), 8-15. Retrieved from http://journal.unnes.ac.id/index.php/jpii

Pembelajaran, K. D. J. dan K. D. (2017). Panduan Penyusunan Perangkat Pembelajaran \& Bahan Ajar 2017. Retrieved from https://pdfcoffee.com/133-panduan-perangkat- 
bahan-ajar-pdf-free.html

Plomp, Tjeerd., Nieeven, N. (2013). Educational Design Research. Retrieved from SLONetherlands Institute for Curriculum Development website: https://www.researchgate.net/publication/265092587_Educational_Design_Resear ch

Sastroadmojo, S. (2018). pengantar statistik pendidikan. Jakarta: Rajawali press. 